\title{
KITEKINTÖ
}

\section{POLITIKAI-TÖRTÉNETI RÉGIÓK A MAGYAR ÉS SZERB ETNIKUMOK ÉRINTKEZÉSI ZÓNÁIBAN ${ }^{1}$}

\author{
(Political-Historical Regions of Contactzones of the Hungarian \\ and Serbien Ethnic Groups)
}

\author{
BENKÖ PÉTER
}

\begin{abstract}
Kulcsszavak:
Bánság birodalom etnikum fejedelemség területi autonómia Vajdaság

A szerb nép államiságának első négy évszázadát idegen birodalmak keretében, korlátozott szuverenitású fejedelemségekben, tehát politikai régiókban élte. Ezt követte a 13-14. században a független királyság idöszaka, majd ismét egy évszázadnyi tartományokra szakadt állapot, részben magyar impérium alatt. A török uralom utolsó évszázadában, a 19. században ismét korlátozott szuverenitású fejedelemség, a 20. században pedig a jugoszláv állam birodalmi jellegü országa következett. A két nép közös politikai régiói: a 18. századi Temesi Bánság és a 20. században létrejött Vajdaság.
\end{abstract}

Mindenekelőtt tisztáznunk kell a politikai-történeti régió fogalmát. Kiindulópontunk maga a régiófogalom. A régió a térben környezetétöl elkülönülö, lehatárolt területi egység a nemzeti (etnikai) és a települési szint között, amelyet a társadalmi folyamatok széles körét átfogó, soktényezős társadalmi-gazdasági összekapcsoltság (kohézió), lakosainak érzékelhető területi összetartozása (identitástudata), illetve érdemi irányítási hatáskörủ és önállóságú regionális intézmények rendszere fog tartós egységbe. Úgy vélem, e meghatározás a politikai-történeti régióra is érvényes, hiszen hordozza annak legfontosabb jellemzöit, a részleges politikai szuverenitás elemeit, mely utóbbit a középkorban a hübéri függés fogalma takarta. A régió egyébként latin eredetű kifejezés, a rex=király szóból származik, a regnum-regio tehát egykoron királyságot jelentett, Itália őslakóinak, egy-egy népének (latinok, etruszkok, szamniszok, szabinok, ligurok stb.) kezdetleges politikai szervezetét takarta. Témánk szempontjából fontos, hogy mindenképpen kis létszámú és lakóterületủ etnikumokról volt szó. Attól kezdve, hogy a latinok (rómaiak) uralmuk alá hajtották a szomszéd népeket, már birodalomépítésröl beszélünk. Kis népek - egészen a 20. századig általában nem tudták tartósan megőrizni szuverenitásukat, mert a környező, erősebb etnikumok birodalomalkotásának áldozataivá váltak, vagy - ritkább esetekben - a szomszéd népek meghódításával maguk hoztak létre impériumokat.

Pontosan erről volt szó a szerb és a magyar nép esetében is. S ami a léptéket illeti, mindkét etnikum politikai-történeti régiói (a mai NUTS 1-hez hasonlóan) hozzáve- 
tőleg 20-60 ezer km² kiterjedésűek, vagyis makrorégiókról beszélhetünk. Így a politikai-történeti nagy térség rokon értelmű lesz a fejedelemség, a nagyzsupánság, a hercegség, a despotaság, a tartomány, a kerület, a bánság és a vajdaság fogalmával, melyeknél kisebb területi egységek a járások, megyék, ispánságok, nagyobb entitások pedig az országok és a birodalmak (királyság, császárság). A politikai-történeti makrorégió (továbbiakban: a régió) egyik fő ismérve, hogy nem öleli fel az adott etnikum teljes egészét, az ország-birodalom fogalma viszont más népek feletti uralmat is feltételez. Az ugyanis sohasem fordul elö, hogy az államhatár pontosan egybeessen a domináns etnikum lakóterületének peremvonalaival, nem ritkán azért, mert - mint pl. a balkáni térségben - gyakran találkozunk kevert lakosságú övezetekkel.

\section{Szerbia a középkorban}

A szlávok őshazája Kelet-Európában, a Dnyeper felső szakasza és mellékfolyói, a Gyeszna és a Pripjaty vidékén terül el, nagyjából a Visztula, a Nyugati Dvina, Moszkva és a Bug folyók közötti térségben (a mai Ukrajna, Belarusszia és Oroszország hármas-határ övezetében), a lombos erdők övében található. Szétvándorlásuk a szélrózsa minden irányába a hatodik században kezdődött, így három nagyobb csoportjuk jött létre: északon és keleten a keleti szlávok (később ukrán, orosz és fehérorosz nép) élnek, a nyugati szlávokat a lengyelek, csehek és szlovákok alkotják, délre, a Balkán felé pedig a szlovének, a horvátok és a szerbek vándoroltak. A különböző délszláv törzsek elöször az 520-as években indítottak módszeres támadásokat a Keletrómai Birodalom ellen, egyes merész csoportjaik az évszázad közepén az Adriához is kijutottak, sőt a Peloponészosz félszigetre is betörtek. Megtelepedni azonban ekkor még nem tudtak, a bizánci csapatok elől később is rendszeresen viszszavonultak az Al-Duna északi partján fekvő „Szklavinába”. Véglegesen a 7-8. században telepedtek le, amikor egyéb támadások következtében összeomlott a Bizánci Birodalom dunai védvonala. A délszlávok hatalmas tömege beékelődött a hunok által alaposan megritkított, romanizált (vlach) és nem romanizált (albán) népek közé (akiket a magas hegyekbe szorítottak), igénybe véve a Balkán legnagyobb részét az Alpoktól és az Al-Dunától Közép-Görögországig (Történelmi... 2001).

A szerbek névadó törzse 626-ban az Al-Dunán átkelve, más szláv törzsek részben ugyanarra, részben Bánát déli szegélyén át költöztek a Balkánra (SokcsevitsSzilágyi I.-Szilágyi K. 1994, 17). (A szlávok jelenléte a Kárpát-medencében a régészeti és történeti források alapján csak a Temesközben mutatható ki a 6-7. században.) A szerb nép a szerb nevet viselő törzs és a már korábban ideköltözött egyéb szláv csoportok összeolvadásából alakult ki. Amikor a 9. században bizánci közvetítéssel felvették a kereszténységet, a Drina folyó alsó folyásának környékén, illetve attól a Moraváig terjedő vidéken, valamint a Kárpát-medencéből a Duna és a Száva közötti Szerémségben, a Tarcal-hegység mentén, vagyis a mai Szerbia központi térségeiben éltek. Ez a terület abban az időben a Bolgár birodalom északnyugati 
határvidékét képezte. A nomád eredetű onogur-bolgárokkal szemben a szlávok, így a szerbek is földművelésből és kisállattartásból éltek. Az utóbbi megállapítás témánk szempontjából azért fontos, mert a békésebb természetü földművelők kevésbé hajlottak hódító hadjáratokra, mint a harcias, szilaj pásztornépek - inkább az utóbbiak céltáblái voltak (Történelmi ... 2001).

Az első szuverén délszláv államot a szerbektől nyugatra, a valamivel nagyobb területen letelepedő horvátok fejedelemség gyanánt 870-ben hozták létre. A két nép közötti különbség kialakulása akkor kezdődött, amikor a horvátok - frank közvetítéssel - a nyugati kereszténységet vették fel, majd a Magyar Királyság alattvalói lettek, s ezzel egyszer s mindenkorra a nyugati kultúrkörhöz csatlakoztak. Az első részleges szuverenitással rendelkező, a bolgároktól függő szerb államalakulat - a kiéleződött bolgár-bizánci küzdelmek kedvező légkörében - szintén a 9. század közepén, valószínűleg a 830-as években, ugyancsak fejedelemségként jött létre. Miközben a Drinától nyugatra eső területe (a mai Kelet-Bosznia) a 925-ben megalakult Horvát Királyság része lett, viszont az ezredfordulótól Magyarországhoz tartozó - ekkor már részben magyarlakta - Szerémség még egy ideig szerb fennhatóság alatt maradt, maga a fejedelemség 986-tól rövid időre ismét a Bolgár Birodalom része lett, majd a következö évszázad elején tartósan a sokadszor újból eröre kapott Bizánci Birodalom autonóm tartományává vált. Szerbia egyébként Ras vagy Rasz székvárosáról Raska Fejedelemség nevet viselte. Innen ered az ország Rascia vagy Rácország, népének pedig a rác elnevezése. (Ras városa a mai Koszovó északi csücskétől kb. tíz km-re északra található.) A fejedelemség, miután nem fedte a teljes szerb etnikum területét, szuverenitása tartósan korlátozott volt, s méreténél fogva (kb. 60 ezer $\mathrm{km}^{2}$ ) is bizvást nevezhetjük politikai régiónak (Történelmi... 2001).

A 11. században ismét megerősödött Bizánc jelentős területeket hódított el Horvátországtól. Ezt a térséget (a mai Bosznia északkeleti részét, tehát a Boszna és a Drina folyók közötti Száva-menti vidéket) katolikus szlávok lakták, akik ettől kezdve már nem tartoztak Horvátországhoz, új etnikumot alkottak, ezért megkülönböztető névvel bosnyákoknak hívták őket - bár a Bosznia elnevezéssel már a 10. század óta találkozunk - s a bizánci hódítással a tőle függő szerb fejedelemség fennhatósága alá kerültek. A 12. század második felében Nemanja István nagyzsupán, Raska fejedelme kiterjesztette uralmát a megyenagyságú másik szerb fejedelemségre, Zétára (kb. 6 ezer km², későbbi neve: Montenegró), majd Koszovó egy részére, sőt Dalmácia egész déli felére, s 1190-ben formálisan is függetlenítette magát a végleg meggyengült Bizánctól. Államának területe - bár korántsem fedte le az összes szerblakta térséget - mintegy 75 ezer $\mathrm{km}^{2}$-t tett ki, tehát csaknem azonos a mai ország mérettel, átmeneti területi egységnek minősíthető a régió és az ország között. Fia, Nemanjic István egész Koszovót meghódította, s 1217-ben koronát kapott a pápától, ezzel ő lett Szerbia első királya. Utódai döntő vereséget mértek a bolgárokra (akik aztán el is szlávosodtak), majd jelentős területeket hódítottak el Bizánctól: Macedóniát, Epiruszt és Thesszáliát. A középkori szerb állam Dusán István (1333-1355) uralkodása alatt érte el legnagyobb kiterjedését - hübérese lett az albán fejedelem és az epiruszi despota -, székvárosát a macedóniai Szkopjébe 
helyezte át, teljesen önállósította a szerb ortodox egyházat és kikiálttatta magát a szerbek és a görögök császárának (cárjának). A Balkán félsziget ekkor legnagyobb birodalmának kiterjedése mintegy 250 ezer $\mathrm{km}^{2}$-t tett ki (hozzávetőleg azonos a 20. századi Jugoszlávia méretével), a cár halála után azonban alkotóelemeire, régióira esett szét. A szerb nép a 15. század első felében hat egymástól független, de a töröktől vagy a magyaroktól gyakran függő tartományban élt, melyek közül a Lazarevicek fejedelemsége volt a legnagyobb. Az utóbbi jórészt lefedte a mai Vajdaság nélkül vett - Szerbiát (kb. 30 ezer $\mathrm{km}^{2}$ volt). Dusán cár halálát követő száz évben az egymással huzakodó szerbek, bolgárok és görögök martalékául estek a török hódításnak, amely közel négy évszázadra mindenféle autonóm régióalakítási kísérletet csírájában elfojtott. (Radó... 1960; Történelmi... 2001).

Az eddig leírtakból látható, hogy a szerb nép zöme államtörténetének első három évszázadát korlátozott szuverenitású fejedelemségben, politikai régióban élte, ezt követte a másfél évszázados királyság, a birodalmi virágkor, majd ismét egy évszázadnyi - részben magyar, részben török függöségü - fejedelemségekre, régiókra szakadt állapot, amelyet hosszú idöre a török uralom váltott fel.

\section{A Magyar Királyság déli határ menti térsége a középkorban}

Ismeretes, hogy a honfoglalás idején és később is jelentős számú szláv népesség élt a Kárpát-medencében. A 11. században - a hosszabb-rövidebb megszakításokkal évezredig a magyar korona felségterületéhez tartozó - mai Vajdaság Autonóm Tartomány túlnyomó részén azonban magyar etnikum lakott. Csupán a Temesköz déli, Duna menti sávjában, Bácska délnyugati csücskében és a Szerémségben találunk vegyes lakosságot. Tisztán szláv, valószínüleg szerb népesség csak a Szerémségben élt, mégpedig úgy, hogy a Duna mentén magyar, a Száva alsó folyásánál szerb, a kettő között vegyes populáció lakott. A két etnikum közötti kapcsolatok fejlődésének jelentős állomásaként értékelhető, hogy a 13. század közepétől, részben rokoni kapcsolatok révén erősödött a magyar befolyás Szerbiában. (Pl. a legnagyobb szerb király, Dusan István anyai ágon magyar származású.) Ennek folytatásaként és a török veszély hatására Lazarevic István fejedelem a 15. század elején Zsigmond király hübérese lett és kiterjedt magyarországi birtokokat kapott, ahova szerb jobbágyokat telepített. Emellett a 14. század végétől Dél-Magyarországon spontán módon történő szerb betelepülésről is vannak adatok. Amikor 1481-ben a Magyarországon birtokokhoz jutott Brankovic Vuk címzetes rác despota magyar csapatokkal hadjáratot vezetett a török kézen levő szerb területek ellen, illetve a későbbi gyakori hasonló betörések során állítólag 200 ezer szerbet telepítettek át Magyarországra (Engel-Kristó-Kubinyi 2001, 260). Ök részben a török által elpusztított falvakban telepedtek le, részben Mátyás király huszárainak számát növelték. A szerb-bosnyák szövetségre döntő vereséget mért 1389-es rigómezei csatát (a szerbek Mohácsát) követő évtől kezdve - amikor is a török megjelent a magyar határnál - úgyszólván évről-évre megismétlődtek az ellenséges betörések. 
Célpontjuk a Szerbiával határos vidék, a későbbi Vajdaság lett. A rendszeres rabló hadjáratok - amelyeknek egyik fó célja a rabszolgaszerzés volt - katasztrofális hatással jártak a vidék termelőerőire. Az érintett térség úgyszólván sivataggá változott, települései elnéptelenedtek, a lakosság - amely eredetileg zömében magyar ajkú volt - vagy áldozatul esett a pusztításoknak, vagy az ország más tájaira vándorolt. A helyükre már a 15. század folyamán a Balkánról menekülő szerb csoportok költöztek, s így a táj etnikuma fokozatosan kicserélödött (Engel-Kristó-Kubinyi 2001).

Ha pillantást vetünk Magyarország Mátyás-korabeli etnikai térképére, némi meglepetéssel állapíthatjuk meg, hogy a hosszú ideig közhelyszerűnek tartott tétel, miszerint a 15. században a Kárpát-medence lakosságának túlnyomó többsége magyar volt, nem állja meg helyét. Az egykor lakatlan határvidéket, gyepüket ugyanis nem magyar, hanem német, szlovák, szász, ruszin, román és szerb etnikumok népesítették be, így pl. a Temesköz Duna menti, egykor néptelen délnyugati térségét szerbek lakták be, viszont Bácska átmenetileg színmagyar lett. A török hódoltság két évszázada és az azt követő telepítések azonban a 15. századhoz képest is teljesen megváltoztatták a régió népességi viszonyait (Történelmi... 2001).

Politikai-történeti régiókkal a Magyar Királyság középkori évszázadaiban a magyar és szerb etnikumok érintkezési zónáiban - Bácskában, a Temesközben és a Szerémségben - nem találkozunk. Ezek a területek akkor nem tartoztak a három tartósan autonóm politikai régióhoz, Horvátországhoz, Szlavóniához és Erdélyhez. A később Vajdaságnak és Bánságnak elnevezett térséget már a vármegye-rendszer kiépítésekor besorolták a középszintủ magyarországi közigazgatási szervezetbe, tucatnyi vármegyébe. Úgyszintén nem tekinthetők politikai régióknak a Bizánccal, majd a Török Birodalommal szemben ütközöövezetekként létrehozott, a vármegye-rendszerhez nem tartozó - egyébként vármegye nagyságú - a Szávától és az Al-Dunától délre a 12-15. században meghódított térségben létrehozott, tisztán bosnyák és szerb lakosságú bánságok. A katonai igazgatású bánságok (Ráma, Boszniai, Jajcai, Ozorai, Sói, Szreberniki, Macsói, Barancsi, Kucsói) még a birodalmi jellegű Szerb Királyság időszakában sem tartoztak Szerbiához, vagy csak némelyik rövid időre (Történelmi... 2001).

A viszonylag rövid életủ, gyakran átszervezett és területileg változó bosnyák és szerb bánságok előkelői olykor helyet kaptak a magyar föurak köreiben, közülük nem egy báni méltóságot is viselt, mint pl. Kotromanic István boszniai bán a 14 . század közepén, akinek - nem mellesleg - Erzsébet nevü leánya Nagy Lajos király felesége lett. A 14-15. század fordulóján egyébként jelentős változás állott be a magyar és szerb domináns elit viszonyában, amíg korábban a magyar királyok a hódító jogán minden ellenszolgáltatás nélkül elvárták, hogy a szerbek vessék alá magukat a magyar uralomnak, később a török elleni összefogás érdekében egyes szerb előkelöségek - mint láthattuk - jelentős birtokokhoz jutottak Magyarországon. Brankovic György szerb despota pl. az együttmüködés fejében megkapta - többek között Debrecen, (Hajdú-)Böszörmény, Szatmárnémeti, Nagybánya, Munkács és Beregszász városokat a hozzájuk tartozó hatalmas uradalmakkal. A szerb lakosság egy részével együtt a Rigómező után megmaradt uralkodó osztály egyes tagjai is Magyarországra menekültek (Engel et al. 2001). 


\section{Bánság és Vajdaság}

A török kiüzése utáni évszázadokban létrehozott déli régiók területe három tájegységből tevődik össze: Bácskából, a Szerémségből és a Temesközből. A Temesköz Temesvár elfoglalása (1552) után e város székhelyével régióméretü török közigazgatási egység, vilajet lett. A török elleni visszafoglaló háborúkat lezáró pozsareváci béke (1718) után az osztrák kormányzat nem ismerte el a régi birtokosok jogi igényeit, s a térséget kincstári tulajdonnak nyilvánítva, Temesi Bánság néven katonai és kamarai igazgatás alá vonta. A német eredetű Bánát elnevezéssel is elhíresült tartomány ekkor nem tartozott Magyarországhoz, közvetlenül Bécsböl igazgatták, területe közel 20 ezer $\mathrm{km}^{2}$ kiterjedésü, etnikailag Európa legtarkább térsége lett a korszak egyetlen magyarok és szerbek által (valamint még sok más nyelvü népességgel) belakott politikai régiója. A Temesi Bánságot, mint önkormányzattal nem rendelkező katonai és kamarai, majd csak kamarai közigazgatási egységet Mária Terézia 1778. évi rendelete szüntette meg, s csatolta vissza területét Magyarországhoz, újjáalakulhattak az önkormányzattal rendelkező nemesi vármegyék: Krassó, Temes és Torontál. (A Temesköz déli és keleti peremén, a felszabadítás után létrehozott, vármegye nagyságú határör-vidék továbbra is közvetlenül Bécs kormányzása alatt maradt.) Ezzel együtt megkezdődött a katonáskodó szerb szabadparasztok jobbágysorba süllyesztése. A képlet hamarosan így nézett ki: magyar földesúr - szerb jobbágy, csak hogy a kiéleződő ellentétek lényegét megértsük (Magyarország...4. 1989).

Az újjászületett megyék azonban kevesebb, mint egy évtized múlva - ha rövid időre is - megszüntek létezni. A II. József által felszámolt vármegye-rendszer helyébe kiépített tíz kerületből álló önkormányzat nélküli adminisztratív irányítási struktúra egyik régiója a Bács-Bodrog és Arad vármegyékkel összevont fenti három megyével létrehozott Temesvári kerület lett. Rendszere azonban nem élte túl a „kalapos” királyt, 1790-ben vele együtt sírba szállt. Az 1848-49-es szabadságharc veresége után a három tájegységet: Bácskát, Bánátot és a Szerémséget ismét elcsatolták Magyarországtól, Temesi Bánság és Szerb Vajdaság néven ismét Ausztria abszolutisztikus tartománya, nagyvajdája pedig Ferenc József lett. Az újabb, mintegy 25 ezer km² kiterjedésủ önkormányzat nélküli politikai régiót 1860-ban szüntették meg, a kiegyezés után pedig a Török Birodalommal szomszédos katonai határörvidéket is felszámolták, az egész térséget a vármegye-rendszerbe sorolták. 1868-tól a Magyar Királyság területén csak egyetlen - széles önkormányzattal rendelkező politikai régió maradt: Horvát-Szlavónország, melynek ettől kezdve részét képezte, más szerblakta térségekkel együtt, a szerb többségü - északi részében már a török kiüzése után Szlavóniához csatolt - Szerém vármegye is (Történelmi... 2001).

A térség lakossága a török hódoltság és a felszabadító háborúk másfél-két évszázada alatt - mint jeleztük - fokozatosan kipusztult, illetve északra menekült. Újranépesítése a török teljes kiűzése után, 1718-at követően kezdődött. Bánát első katonai parancsnoka, Mercy tábornok legnagyobbrészt németeket telepített a Temes- 
közbe. A kisebb számú olasz, spanyol és francia bevándorolt hamarosan elnémetesedett. A második nagy német telepes hullám az 1763. évi benépesítési rendelet után érkezett. Az 1737-1739 közötti vesztes háború, illetve török támadás után Mária Terézia a megtorlás elől menekülő szerbeket, macedónokat, görögöket, bolgárokat és románokat telepítette a térségbe. A 18. század végétől szlovákok, sőt a 19. század második felében csehek is érkeztek. Magyarok jórészt csak 1778 után költözhettek ide, amikor megszünt a kamarai közigazgatás. A török birodalmi szerb autonóm fejedelemség megalakulása, 1817 után viszont nem magyar nemzetiségüek csak elvétve költöztek a Temesközbe. Az első jelentősebb szerb beköltözés 1690-ben történt, amikor is 36-37 ezer (Sokcsevits-Szilágyi-Szilágyi 1994, 37) szerb érkezett Csernojevic Arzén pátriárka vezetésével - jelentős részben Koszovóból - a Szerémségbe és Bácska déli részébe, majd - az egykori ipeki apátság helyett - Karlócán egyházi központot hoztak létre. (A megtorlásokat és az exodust követően a hódoltsági Szerbia, vagyis a belgrádi pasalik lakosainak száma a korábbinak egy tizedére csökkent [Sokcsevits-Szilágyi I.-Szilágyi K. 1994, 50]). Ezzel a szerbség kulturális centruma is áttevődött a Balkánról a Szávától északra. I. Lipót, aki török-ellenes felkelésre szólított fel, cserébe autonómiát, saját vajda választásának lehetőségét ígérte, kiváltságlevelet adott ki, melynek sajátos értelmezése alapján a karlócai pátriárka Mária Terézia koráig bizonyos ügyekben világi hatalmat is gyakorolt, ami megalapozta a későbbi külön-kormányzatra vonatkozó igényeiket. A Habsburg-uralkodók a letelepültek fegyveres erejére támaszkodva szervezték meg a Határőrvidéket. A Vajdaságnak, mint különálló területi egységnek a követelése először 1790-ben a II. Lipót által összehívott szerb nemzeti kongresszuson fogalmazódott meg. 1848-ban a forradalmi magyar kormánnyal szembeforduló szerbek karlócai gyülésükön kimondták a Vajdaság megalakulását és Supljikac szerb határőrezredest vajdává választották. Erre épült a már említett 1849 utáni Szerb Vajdaság és Temesi Bánság (Magyarország...4-6. 1987).

Bánát lakosságának száma az 1770-es évekre 450 ezerre, 1788-ra egyes adatok szerint 600 ezerre, más források alapján kb. egymillióra nőtt (Magyarország... 4/1 1989, 55-56). Ezzel nem egészen egy évszázad alatt az ország legritkábban lakott régiójából egyik legsürübb népességü tájegységévé vált. Az egész térségbe jelentős számban bevándorló magyarok és németek fokozatosan többségbe kerültek a délszlávokkal szemben. Ha a 18. század végi területi megoszlást nézzük, a belakott térségek nagyobb részén: Bácska déli harmadában, a teljes Szerémségben és a Temesköz délnyugati felében túlnyomórészt szerbek, az utóbbi (Bánát) északkeleti felében pedig románok éltek. Magyarok kompakt egységben csak a Kiskunság és Bácska határán, a Baja-Szeged tengely mentén fordultak elő, máshol a németekkel együtt csupán szórványokat képeztek, s a térségnek közel harmada még lakatlan volt. Az utóbbiakat népesítették be jórészt magyarok. A magyar és német populációs többség - a szerb és román területi túlsúllyal szemben - úgy jött létre, hogy jórészt a városok és sürün lakott környékük magyarosodott el (Történelmi... 2001). 
Összefoglalásként megállapíthatjuk, hogy bár a szerb nép által lakott magyarországi területek nem alkottak külön territóriumot, a szerbek mégis rendelkeztek feudális kiváltságokkal, amelyek - a horváthoz hasonlóan - nem kis szerepet játszottak nemzeti törekvéseik támogatásában. Ezek a 17. század végén - a már említett I. Lipóttól nyert kiváltságok a pravoszláv egyház számára önkormányzatot biztosítottak, ami lehetővé tette az egyházi kongresszusok összehívását. E kongresszusokat a pátriárka vezette, aki egyben a szerb nemzet feje is lett. A privilégiumok ígéretet is tartalmaztak külön szerb hivatal és terület megszervezésére. A görögkeleti egyházinemzeti privilégiumok szelleme magában foglalta a szerb területi különállást. Ezekre épült a territoriális kívánság, a szerb vajdaság létrehozása. A világi funkciókat is ellátó autonóm egyház (a szerb község pópája gyakran a falu vezetöje is volt) felvetette ezt a kívánalmat is. Ennek révén a teokratikus eredetủ területi autonómia polgári tartalmat kapott. A 20. századi Jugoszláviában testet öltött Vajdaság történelmi előzményei ide nyúlnak vissza.

\section{Az autonóm Szerbiától a jugoszláv Vajdaságig}

Szerbia felszabadítására irányuló 18 . századi kísérletek nem vezettek eredményre. A 19. század eleji felkelések azonban - orosz segítséggel - 1817-re meghozták a szerb autonómiát a Török Birodalom keretében. A mai Szerbia központi régiója a Drina-Száva-Duna és a nyugati Balkán-hegység előtere közötti terület - mintegy 38 ezer $\mathrm{km}^{2}$, több mint félmillió lakossal, mint függő fejedelemség 1838-ban még alkotmányt is kapott. Az 1877-es felkelés és az ezt követő szerb-orosz-török háború után bekebelezhette a Nis környéki térséget - 11 ezer $\mathrm{km}^{2}$-t - és független királysággá vált. Egyéb téren azonban régiójellegü maradt, hiszen a szerb nemzetnek fele sem élt az új államban, területe pedig csupán 50 ezer $\mathrm{km}^{2}$ körül lehetett, tehát átmenetet jelentett a regionális és a nemzeti szint között. A királyság ország méretủ állammá csak az 1912-13-as balkáni háborúk során vált, megszerezve a szerblakta Szandzsákot (Novi Pazar környékét), az albán többségű Koszovót, valamint Macedóniát. Ezzel az ország területe mintegy 90 ezer $\mathrm{km}^{2}$-re, lakossága négy és félmillióra növekedett, de még mindig milliónyi szerb élt az Osztrák-Magyar Monarchiában, viszont nem sokkal kevesebb idegen ajkú (albán, macedón) népességgel kellett megbirkóznia (Magyarország...4. 1989).

A Vajdaság etnikai összetétele a 19-20. század fordulójára alaposan megváltozott. Annyiban hasonlított a száz évvel korábbi helyzetre, hogy egyik nemzetiség sem került abszolút többségbe, viszont jelentősen megnőtt a magyar elem aránya, Bácskában és a Tisza-Maros szögében összefüggő területet alkottak, német, szerb és szlovák szórványtelepülésekkel. A Szerémségben és a Duna-Tisza összefolyása környékén a szerbek erős többséget képeztek, kevés horvát, magyar, szlovák és német folttal. A németek a Duna-mentét uralták, nagymértékben keveredve az imént felsorolt etnikumokkal, Bánát északnyugati negyedében pedig összefüggő 
területet laktak. A Temesköz északkeleti fele csaknem teljesen román térség. A hamarosan Szerbiához csatolt Vajdaság lakosságának több mint 60\%-át magyarok és németek tették ki (Magyarország...8. 1984).

Az Osztrák-Magyar Monarchia első világháborús vereségét és széthullását követően, 1918. november 25-én a vajdasági szerbek és más délszlávok újvidéki gyülése a többségi magyar és német etnikumok megkérdezése nélkül kimondta a terület csatlakozását az új délszláv államhoz. Döntésüknek nyomatékot adott az a tény, hogy a szerb királyi hadsereg (és két francia hadosztály) a Barcs-Pécs-BajaSzeged-Makó vonalig megszállta a térséget. A trianoni békeszerződés e városokat és közvetlen környéküket nem, de a baranyai háromszög, Bácska és Bánát legnagyobb részét elszakította Magyarországtól, köztük Magyarkanizsa, Szabadka és Zenta magyar többségủ körzeteit. Az utóbbi lépésnek stratégiai okai is lehettek, ugyanis el akarták vágni a kijelölt határ magyar oldalán futó Nagykanizsa-BarcsPécs-Baja-Szabadka-Szeged-Gyula vasúti fővonalat (Magyarország...8. 1984).

A Szerb-Horvát-Szlovén Királyság létrejöttével megvalósult a szerb nemzet évszázados vágya, valamennyi nemzettársuk, sőt a bolgárok kivételével minden délszláv nép közös államban egyesült. Autonómiát azonban sem a Vajdaság, sem a nem szláv népek nem kaptak, sőt az 1929-ben Jugoszlávia néven létrejött királyi diktatúra még az államalkotó horvát és szlovén nemzetek jogait is korlátozta. Ezzel el is vetették az egységes állam széthullásának magvait, amelynek termését az 1941-es német támadás aratta le. 1941-1944 között Bácska Magyarországhoz tartozott, de Horthyéknak ugyanúgy eszük ágában sem volt autonómiát adni, mint két évtizeden át a Karagyorgyevicoknak, sőt az újvidéki vérengzéssel a végsőkig fokozták az etnikai feszültséget (Magyarország...8. 1984).

A második világháborúban győztes kommunista partizánok 1944-1945-ben elüzték a közel háromnegyedmilliós német kisebbséget, de sok magyar is elmenekült helyükre nagyrészt szerbek költöztek - ezzel Vajdaság lakosságának fele szerb lett, közel negyede magyar maradt (ma kétharmada szerb, egyhetede magyar). Jugoszláviát pedig föderatív állammá alakították (Radó 1960, 464; Nagy... 2008, 322). Albánia és Bulgária részvételével tervezett balkáni konföderáció létrejöttét ugyan Sztálin magakadályozta, ennek ellenére - $255804 \mathrm{~km}^{2}$ területtel - Tito állama lett a térség, Délkelet-Európa legnagyobb kiterjedésủ és lélekszámú országa, egy kisebbfajta birodalom. Az el nem kötelezettek világmozgalmában betöltött szerep pedig középhatalmi státust biztosított számára. A Vajdaság 21 és félezer $\mathrm{km}^{2}$ területével, másfélmillió lakójával Szerbia autonóm tartományává válhatott. Önállóságát az 1963-as és az 1974-es jugoszláv alkotmány tovább növelte, az utóbbi csaknem tagköztársasági szintre emelte, önkormányzati tevékenysége azonban - a kommunista diktatúra által megvalósított centralizáció rendszerében - csupán igen korlátozott lehetett (Gulyás 2009, 157, 166). Milosevic 1989-ben leszúkítette a Vajdaság Autonóm Tartomány jogkörét, gyakorlatilag formálissá tette az önkormányzatot, amelyet a 2000 őszén hatalomra került szerb demokratikus ellenzék is csak részlegesen állított vissza. 2002ben azonban újra megalakulhatott a vajdasági parlament, a 2006-os alkotmány pedig tovább szélesítette a tartomány autonómiáját (Gulyás 2009). 
A szerb nép 1991 és 2000 között 14 évszázados történetének egyik legsúlyosabb vereségsorozatát szenvedte. Ezt azért is érezhették traumának, mert az utóbbi két és fél évszázadban minden háborút megnyertek. Magyar szemmel nézve valóban trianoni méretü veszteség érte őket: a történelmi Magyarország méreteit közelítő Jugoszlávia hegemón nemzetének, s szövetségi államának, Szerbiának a szuverenitása alatt az egykori délszláv föderáció területének kevesebb, mint egyharmada, 77 és félezer $\mathrm{km}^{2}$ maradt. A jó nyolcmilliós szerb etnikum közel egyharmada (és akkor még nem beszélünk a szerb nyelvet beszélő bosnyákokról és montenegróiakról) a szomszédos függetlenné vált államokban rekedt, a sorozatos háborúk pedig az ország súlyos veszteségeihez és elszigetelődéséhez vezettek (Nagy... 2008, 322). Napjaink Szerbiája alig nagyobb területü, mint a 12 évszázada létrejött Raska Fejedelemség, hasonlóan a trianoni Magyarországhoz, amely szintén csak valamivel kisebb, mint a honfoglaló Árpád fejedelemsége által megszállt térség volt. Számukra - akár a környező országoknak - tartós megoldást csupán az európai integráció hozhat.

\section{Jegyzet}

${ }^{1}$ Az MRTT Szabadkán, 2009. november 12-13-án rendezett vándorgyủlésen elhangzott előadásának szerkesztett változata.

\section{Irodalom}

Engel P.-Kristó Gy.-Kubinyi A. (2001) Magyarország története 1301-1526. Osiris Kiadó, Budapest. Gulyás L. (2009) Regionalizáció, regionalizmus és nemzeti kérdés a titói Jugoszláviában 1945-1980. Tér és Társadalom. 2. 155-169. o.

Magyarország története tíz kötetben, 1, 3-8. köt. (1980-1988) Pach Zsigmond P. (szerk. biz. eln.) Akadémiai Kiadó, Budapest.

Nagy Világatlasz (2008) Nyír-Karta kiadó, Budapest.

Radó S. (szerk.) (1960) Nemzetközi almanach 1960 Kossuth Könyvkiadó, Budapest.

Sokcsevits D.-Szilágyi I.-Szilágyi K. (1994) Déli szomszédaink története. Bereményi kiadó, Budapest.

Történelmi atlasz. (2001) Cartographia, Budapest. 